\title{
The Effect of Interferon and Ribavirin on Oxidative Stress in Chronic Hepatitis C Patients
}

\author{
Maggie M. Ramzy and Hend M. Abdel-Ghany \\ Biochemistry Department, Faculty of Medicine, Minia University
}

\begin{abstract}
Hepatitis $C$ virus is the most common cause of chronic viral hepatitis. The hepatic damage is due to both the cytopathic effect of the virus and the inflammatory changes. Oxidative stress could play a role in pathogenesis of hepatitis $C$ virus infection. The aim of the present study is to determine oxidant/antioxidant status of patients with chronic hepatitis $C$ and the effect of alpha-interferon plus ribavirin combination therapy on oxidative stress. Twenty patients with chronic hepatitis $C$ and ten healthy controls were included in the study. Erythrocytes reduced glutathione (GSH), superoxide dismutase (SOD) and plasma total sulfhydryl group (tSH) were measured before and after 3 and 6 months of treatment and in control group and correlated with serum AST, ALT and viral load. Our results showed that there was reduction in erythrocyte GSH, SOD and plasma tSH in patients with chronic hepatitis $C$ and they began to rise significantly early after 3 months of treatment and sometimes normalize after 6 months. Also, there were significant negative correlations between these parameters and liver enzymes (ALT and AST) and viral load. The present study showed presence of oxidative stress in chronic hepatitis $C$ patients. Although interferon and ribavirin are not antioxidants, they promote an early inhibition of oxidative stress. This suggests that antioxidant supplementation might be considered in patients with chronic hepatitis $C$.
\end{abstract}

\section{INTRODUCTION}

Hepatitis C Virus (HCV) is considered the most common etiology of chronic liver disease in Egypt ${ }^{[1]}$. It is also associated with hepatocellular carcinoma ${ }^{[2]}$. The net liver damage from $\mathrm{HCV}$ infection depends on the balance between the host's antiviral mechanisms and the ability of the virus to subvert them ${ }^{[3]}$.

HCV may cause oxidative stress in infected cells. Several lines of evidence support this connection, including the existence of activated glutathione turnover, the presence of increased levels of lipid peroxidation products and augmented iron stores in the liver ${ }^{[4]}$.

The biological effects of free radicals are controlled by many antioxidants including reduced glutathione (GSH) and $\beta$-carotene. GSH detoxifies hydrogen peroxide $\left(\mathrm{H}_{2} \mathrm{O}_{2}\right)$ and other organic peroxides to prevent their harmful effects. It also maintains the sulfhydryl (-SH) groups of proteins in the reduced state to protect them from oxidation ${ }^{[5]}$. GSH is decreased in the blood serum of patients with chronic hepatitis $\mathrm{C}$ (CHC) who are not treated with interferon ${ }^{[6]}$.

The level of glutathione peroxidase (GSH-Px) was shown to 
be diminished in serum and erythrocytes of children with abnormal liver functions ${ }^{[7]}$ and there was low activity of GSH-Px and superoxide dismutase (SOD) in adults with acute hepatitis $\mathrm{B}^{[\mathbf{8}]}$.

Lipid peroxidation is caused by free radicals leading to oxidative destruction of polyunsaturated fatty acids which are constituents of cellular membrane ${ }^{[4]}$. Hydrogen peroxide is not considered as a free radical, but it stimulates damage to the tissues. Superoxide dismutase is an enzyme that catalyzes the dismutation of two superoxide anions $\left(\mathrm{O}_{2^{-}}\right)$into hydrogen peroxide and molecular oxygen then catalase enzyme hydrolyzes $\mathrm{H}_{2} \mathrm{O}_{2}$ into $\mathrm{H}_{2} \mathrm{O}$ and $1 / 2 \mathrm{O}_{2}$. The activity of these enzymes plays an important role in the process of the disease and the care of viral hepatitis C patients. Superoxide dismutase protects the tissue to a certain degree from the harmful effects of superoxide radicals ${ }^{[9]}$.

Increased SOD activity appears to be an adaptive response to increased generation of superoxide ions ${ }^{[\mathbf{1 0 ]}}$ and the reduction in the amount of SOD reflects a decrease in the synthesizing capacity of liver, and the antioxidant defense power of the patients with $\mathrm{CHC}^{[11]}$.

Sulfhydryl groups occur as nonprotein compounds in free cysteine and in protein such as thioredoxin, glutaredoxin and albumin, which is the chief protein constituent of blood plasma $^{[12,13]}$. Thiol group (-SH) plays a prominent role in antioxidant reactions, and also in reactions of catalysis, regulation, electron transport and those preserving the correct natural structure of proteins
[14]. The redox status of plasma thiols can be a diagnostic indicator of different pathological states ${ }^{[15]}$ and the total sulfhydryl group (tSH) content of a biological sample is a valuable indicator of oxidative stress and of oxidative protein damage ${ }^{[16]}$. Total plasma sulfhydryl groups (tSH), reflecting the antioxidant capacity of the plasma, were found to be decreased in hepatitis $\mathrm{C}$ patients ${ }^{[17]}$.

Because of repeated biopsies are needed to evaluate disease progression $^{[\mathbf{1 8 ]}}$, many attempts have been made to find serological or cellular markers that help in the clinical management and evaluation of treatment response of chronic hepatitis $\mathrm{C}$ (CHC) patients. These include plasma viral load, plasma anti-HCV IgM or other soluble immune factors, hepatic viral $\mathrm{RNA}^{[4]}$. Although interferon-alpha is still used in treatment of chronic viral hepatitis, its effect on oxidants and antioxidants status is not well known and may be significant in deciding on the type of therapy, follow-up and prognosis of patients ${ }^{[4]}$.

The present study was undertaken to evaluate oxidative stress in chronic hepatitis $\mathrm{C}$ patients by several potential oxidative stress markers in plasma and erythrocytes and further to evaluate the effect of the treatment on these biomarkers and their correlation with liver enzymes and the viral load.

\section{MATERIALS \& METHODS}

\section{Patients:}

Twenty patients (11 males and 9 females), mean age 45 years, with chronic HCV infection were included in the present study. The patients 
group was selected from Liver Unit of Minia Healthy Insurance Hospital. Patients with hepatitis were diagnosed in the Department of Infectious Diseases of that Hospital. The diagnosis of the patients was based on elevated serum transaminases, positivity for anti-HCV antibodies and the presence of HCV-RNA in serum. Also, a per-cutaneous liver biopsy was performed in the patients with chronic hepatitis in the same Unit by standard techniques using an appropriate tissue biopsy needle. The patients with other chronic or autoimmune liver diseases were excluded from the study.

Patients with $\mathrm{CHC}$ were started on IFN- $\alpha$ and Ribavirin treatment. They received their therapy once a week for a period of 6 months. Blood samples were drawn before and after 3 and 6 months of treatment.

\section{Control group:}

The control group consisted of 10 healthy individuals (6 males and 4 females), mean age 43 years. They were selected from volunteers came to the Liver Unit of Minia Healthy Insurance Hospital. They were seronegative for $\mathrm{HCV}, \mathrm{HBV}$. They showed no abnormal laboratory findings including liver function tests. The controls had no history of any liver disease, alcohol or any other chronic drug use.

\section{Laboratory investigations:}

Blood samples were drawn from the control and the patients into tubes containing EDTA. They were centrifuged at $4000 \mathrm{~g}$ for 10 minutes at $4{ }^{\circ} \mathrm{C}$. After separation of the plasma, the buffy coat was removed and the packed cells washed three times with two volumes of isotonic saline. Then, the erythrocytes were lysed with cold distilled water (1:4), stored in a refrigerator at $4^{\circ} \mathrm{C}$ for 15 minutes. The cell debris was removed by centrifugation $\left(2000 \mathrm{~g}\right.$ at $4^{\circ} \mathrm{C}$ for 10 minutes). The plasma and erythrocytes lysates were stored at $70^{\circ} \mathrm{C}$ until assayed.

Reduced glutathione and SOD were measured in erythrocyte lysate while tSH was measured in plasma. Data of ALT, AST and viral load are obtained from the Liver Unit.

\section{Measurement of reduced} glutathione: Reduced glutathione was measured using colorimetric assay kit provided by Biodiagnostic, Egypt according to the manufacturer's instruction. The method is based on the reduction of 5, 5'-dithiobis (2-nitrobenzoic acid) with reduced glutathione to produce a yellow colored compound. The values were expressed as $\mathrm{mmol} / \mathrm{g}$ $\mathrm{Hb}^{[19]}$.

2. Measurement of superoxide dismutase: Total SOD activity was measured using colorimetric assay kit provided by Biodiagnostic, Egypt as indicated by the manufacture's instruction. The assay relies on the ability of the enzyme to inhibit the phenazine methosulphate-mediated reduction of nitroblue tetrazolium dye. SOD activity is given in $\mathrm{U} / \mathrm{g} \mathrm{Hb}^{[20]}$.

3. Measurement of total plasma sulfhydryl groups (t-SH): t$\mathrm{SH}$ groups were measured using Ellman's reagent 5,5-dithiobis-2 nitrobenzoic acid (DTNB). The thiol-disulfide interchange reaction between DTNB and thiols was the basis of that spectrophotometric

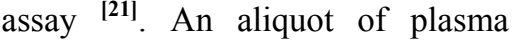
$(0.20 \mathrm{ml})$ was mixed in a $10 \mathrm{ml}$ test 
tube with $0.6 \mathrm{ml}$ of Tris $(0.25 \mathrm{M})$ EDTA $(20 \mathrm{mM})$ buffer, followed by addition of $40 \mu \mathrm{l}$ of $10 \mathrm{mM}$ DTNB and $3.16 \mathrm{ml}$ of absolute methanol. The tubes were capped, and the color was developed for 15-20 minutes, followed by centrifugation at $3000 \mathrm{~g}$ for 10 minutes at ambient temperature. The absorbance of the supernatant at $412 \mathrm{~nm}$ (A) was subtracted from a DTNB blank (B). Total SH groups were calculated as follow: (A-B) x $1.47 \mathrm{nM}$. The results are expressed as micromoles t-SH per gram protein after determination of total protein content of the sample with Lowery assay $^{[22]}$.

\section{Statistics Analysis:}

All data are presented as mean + SD. Significant difference among data were determined using independent Student's t test with SPSS version 13 and the correlation between the biochemical parameters were performed using Pearson's correlation coefficient (r). P value below 0.05 was considered significant.

\section{RESULTS}

Our data are presented in table 1 as mean + standard deviation showing the difference between the four groups in erythrocyte GSH, SOD and plasma $\mathrm{tSH}$.

It was found that the erythrocyte GSH level was significantly decreased in patients of CHC (group II) compared to control group while after treatment (group III and group IV) it is significantly increased compared to group II but it was higher after 6 months of treatment. These findings showed that the treated patients are under the influence of increased oxidative stress.

The level of erythrocyte SOD was found to be significantly lower in hepatitis patients and begins to rise significantly after 3 months and continue rising till 6 months of treatment suggesting that interferon and ribavirin might be effective in the treatment of liver damage by improving the antioxidant system.

The level of plasma $\mathrm{tSH}$ was significantly decreased in hepatitis group and an increase was seen after 3 months of treatment reaching normalization after 6 months of treatment suggesting that antioxidative capacity of the plasma plays a role in viral hepatitis and its treatment.

Table 1: GSH, tSH concentration and SOD activity in the control group and in CHC patients before and after treatment (mean \pm S.D).

\begin{tabular}{|l|l|l|l|l|}
\hline Parameter & $\begin{array}{l}\text { Group I } \\
\text { (Control) }\end{array}$ & $\begin{array}{l}\text { Group II, } \\
\text { CHC before } \\
\text { treatment }\end{array}$ & $\begin{array}{l}\text { Group III, } \\
\text { After 3 months } \\
\text { treatment }\end{array}$ & $\begin{array}{l}\text { Group IV, After } \\
\text { 6 months } \\
\text { treatment }\end{array}$ \\
\hline $\mathrm{GSH}(\mathrm{mmol} / \mathrm{g} \mathrm{Hb})$ & $6.06 \pm 0.61$ & $3.37 \pm 0.46^{*}$ & $4.25 \pm 0.42^{* *}$ & $5.03 \pm 0.31^{* *}$ \\
\hline $\mathrm{SOD}(\mathrm{U} / \mathrm{g} \mathrm{Hb})$ & $603.3 \pm 12.2$ & $473.6 \pm 21.4^{*}$ & $536.8 \pm 19.6^{* *}$ & $569.3 \pm 16.8^{* *}$ \\
\hline $\mathrm{tSH}(\mu \mathrm{mol} / \mathrm{g}$ prot. $)$ & $8.96 \pm 0.4$ & $7.04 \pm 0.3^{*}$ & $8.02 \pm 0.3^{* *}$ & $8.6 \pm 0.4^{* *}$ \\
\hline
\end{tabular}

* Significant comparing with control group.

** Significant comparing with group II (CHC before treatment). 
Table 2: AST, ALT activity and vital load concentrations in the control group and in $\mathrm{CHC}$ patients before and after treatment ( $($ mean \pm S.D).

\begin{tabular}{|l|l|l|l|l|}
\hline Parameter & $\begin{array}{l}\text { Group I } \\
\text { (Control) }\end{array}$ & $\begin{array}{l}\text { Group II, CHC } \\
\text { before treatment }\end{array}$ & $\begin{array}{l}\text { Group III, After 3 } \\
\text { months treatment }\end{array}$ & $\begin{array}{l}\text { Group IV, After 6 } \\
\text { months treatment }\end{array}$ \\
\hline AST (U/ L) & $24.3 \pm 2.9$ & $52.0 \pm 20.3^{*}$ & $39.3 \pm 23.2^{* *}$ & $28.3 \pm 6.2^{* *}$ \\
\hline ALT (U/ L) & $28.7 \pm 4.2$ & $56.6 \pm 18.5^{*}$ & $31.6 \pm 11.4 * *$ & $27.6 \pm 6.9^{* *}$ \\
\hline Viral load IU/ml & ${ }^{\text {a }}$ Negative & $\begin{array}{l}767303.8 \\
\pm 946485.9 *\end{array}$ & Undetectable** & Undetectable** \\
\hline
\end{tabular}

* Significant comparing with control group.

** Significant comparing with group II (CHC before treatment).

a The meaning of "not detected" or "negative" differs, depending on the test used. In this lab, the detection limit for the "quantitative" HCV RNA test by "PCR" is 12 $\mathrm{IU} / \mathrm{ml}$.

We found that there is a significant negative correlation between erythrocyte GSH, SOD and plasma tSH and liver function parameters ALT and AST as these parameters highly increased in CHC patients and decreased with the treatment (table 3 ). Also, there was negative correlation between antioxidant parameters and viral load which was significant with SOD and tSH but insignificant with GSH ( $r=-0.30$, $\mathrm{p}=0.053$ ).

Table 3: Correlation between GSH, SOD and tSH with liver parameters (ALT $<$ AST) in the control group and in CHC patients before and after 3, and 6 months treatment and between these parameters and viral load in $\mathrm{CHC}$ patients before treatment.

\begin{tabular}{|l|l|l|l|}
\hline \multicolumn{2}{|l|}{ ALT } & AST & Viral load \\
\hline GSH & $\mathrm{N}=70 \mathrm{r}=-0.51 \mathrm{p}=0.001^{*}$ & $\mathrm{~N}=70 \mathrm{r}=-0.64, \mathrm{p}=0.0001^{*}$ & $\mathrm{~N}=20 \mathrm{r}=-0.30 \quad \mathrm{p}=0.053$ \\
\hline SOD & $\mathrm{N}=70 \mathrm{r}=-0.56 \mathrm{p}=0.0001^{*}$ & $\mathrm{~N}=70 \mathrm{r}=-0.45 \mathrm{p}=0.004^{*}$ & $\mathrm{~N}=20 \mathrm{r}=-0.52 \mathrm{p}=0.001^{*}$ \\
\hline tSH & $\mathrm{N}=70 \mathrm{r}=-0.63 \mathrm{p}=0.0001^{*}$ & $\mathrm{~N}=70 \mathrm{r}=-0.52 \mathrm{p}=0.0001^{*}$ & $\mathrm{~N}=20 \mathrm{r}=-0.51 \mathrm{p}=0.001^{*}$ \\
\hline
\end{tabular}

* Significant as correlation is significant at the 0.05 level. $\mathrm{N}=$ number of samples

\section{DISCUSSION}

$\mathrm{HCV}$ is considered the most common etiology of chronic liver disease in Egypt $^{[23]}$. Although the main role of immunological mechanisms in pathogenesis of the chronic viral hepatitis $\mathrm{B}$ and $\mathrm{C}$ was demonstrated, researches also concentrate on the problem of oxidative stress in the pathology of the disease $^{[4]}$. The results of the present study confirm that patients with chronic hepatitis $\mathrm{C}$ are in oxidative stress. Although interferon is still used in the treatment of hepatitis, its effects on the oxidant and antioxidant status 
of patients is not well known ${ }^{[11]}$ and although interferon and ribavirin are not antioxidants, their antiviral capacity might reduce viral load and inflammation and perhaps though that mechanism might reduced virusinduced oxidative stress ${ }^{[4]}$.

Our results show that GSH level in patients with $\mathrm{CHC}$ was significantly lower compared to those of the healthy control. Such finding was in agreement with Suarez and his colleagues who studied a group of 100 individuals with chronic hepatitis $\mathrm{C}$. They demonstrated that GSH was decreased in the blood of patients who was not treated with interferon ${ }^{[24]}$. Confidently, it is known that GSH, a tripeptide that is synthesized in the liver by enzymatic reaction, is also a significant antioxidant ${ }^{[11]}$. Therefore, the reduction in the amount of GSH reflects both a decrease in the synthetic capacity of the liver and the antioxidant defense power of patients with viral hepatitis C. In contrast, GSH was significantly higher in blood of patients receiving interferon and ribavirin for 3 and 6 months.

In assessment of the correlation between reduced glutathione and some hepatitis parameters it was found that there is a negative correlation with both ALT and AST activity, while there was insignificant correlation with viral load, that finding may be due to that the number of HCV-RNA copies/ml varied considerably from patient to patient, and in a previous study it was found that there is no correlation between viral load and the level of ALT ${ }^{[25]}$. Also, it was reported that when a glutathione precursor was used with interferon, such treatment increased the level of antioxidant enzyme and decreased the activity of ALT ${ }^{[26]}$.

Although some researchers found that SOD may be increased in acute period but the level of enzymes decreased in the chronic period of the disease ${ }^{[9]}$. Others also found that SOD was significantly decreased in CHC patients before treatment when compared with healthy subjects ${ }^{[4]}$. That result is consistent with our results as we found that SOD activity was decreased in $\mathrm{CHC}$ patients before treatment. Increased lipid peroxidation is caused by the inflammation related to viral infection and decreased the antioxidant level may be an early marker of the oxidative stress ${ }^{[11]}$.

In a previous study it was shown that the average SOD activity in erythrocyte was significantly increased after 48 weeks of treatment with interferon and ribavirin ${ }^{[4]}$, while our results showed that this effect may be earlier as after 3 and 6 months of treatment there was significantly increase in SOD compared to the $\mathrm{CHC}$ patients.

Our study showed that there is a negative correlation between erythrocyte SOD and ALT, AST and viral load. This was in reverse with a previous study which showed that the activities of SOD did not correlate with the HCV-RNA levels [27]. However, Irmisch and his colleagues concluded the same results as they found that into the various patient groups, liver enzymes activities were associated in a significantly negative way with antioxidants ${ }^{[28]}$.

The third biomarker of oxidative stress studied in our patients was plasma tSH which allows a global 
evaluation of the patient's antioxidant defenses ${ }^{[25]}$. It was found that it is significantly decreased in the patients of $\mathrm{CHC}$ and began to rise again after 3 months and continue in rising after 6 months. That result is in agreement with a previous study which reported that values started to normalize from the third month of treatment and were maintained during the follow-up period $^{[25]}$.

By assessment of N-terminal propeptide of procollagen type III (PIIIP), a useful marker of fibrogenesis in the serum of patients [29], it was found that neither grading nor staging were correlated with plasma tSH level ${ }^{[25]}$, however in our study there were significant negative correlation between plasma tSH and liver enzymes and also between $\mathrm{tSH}$ and viral load.

To our knowledge it is the first time to describe the correlation between plasma tSH and viral load, AST and ALT. This test is regularly done before treatment but may be a promising one.

As previously reported interferon prevents further development of fibrosis and improves serological markers of fibrogenesis ${ }^{[29,30]}$ and in previous study it had been indicated that the oxidative stress is related with the activation of Hepatic Stellate Cells (HSCs), which are the central mediators in the pathogenesis of liver fibrosis ${ }^{[31]}$, so one of the possible mechanisms of the action of interferon, explaining its anti-fibrotic effect, is by decreasing oxidative stress through the reduction of reactive oxygen species from HSCs.

The present study showed presence of oxidative stress in chronic hepatitis $\mathrm{C}$ patients and the effect of interferon and ribavirin on different oxidative markers after 3 and 6 months of treatment which may be helpful in follow-up and prognosis of the patient. Such early normalization of biomarkers may predict future response of the disease. Larger series of patients are necessary to confirm that point and further studies are suggested to evaluate these markers after the arrest of treatment.

\section{Acknowledgment:}

We thank Dr. Wessam Meneisi and all workers in Liver Unit of Minia Healthy Insurance Hospital for their assistance in collecting samples and in providing some laboratory data.

\section{REFERENCES}

1- Esmat S. and Omran D. (2011). Study of the right liver lobe size /albumin ratio as a noninvasive predictor of esophageal varices compared to: spleen size, platelet count and platelet count/spleen diameter ratio in post hepatitis $\mathrm{C}$ virus liver cirrhosis in Egypt. J. Am. Sciences 7(1): 962-968.

2- Ebeid ME and El-Bakry KA (2009). Cellular immune response to infection by different genotype of hepatitis $\mathrm{c}$ virus. Indian $\mathrm{J}$. Clin. Biochem., 24 (3) 234-240.

3- Ufearo H, Kambal K, Onojobi GO, Nouraie M, Agbemabiese C, Diaz S, Aggarwal A, Aliyu Z, Taylor RE, Gordeuk VR. (2010) .Complete blood count, measures of iron status and inflammatory markers in innercity African Americans with undiagnosed hepatitis $\mathrm{C}$ 
seropositivity. Clin Chim Acta 411 (9-10):653-6.

4- Levent G, Ali A, Ahmet A, Polat EC, Aytaç C, Ays E, e2 and Ahmet S. (2006). Oxidative stress and antioxidant defense in patients with chronic hepatitis $\mathrm{C}$ patients before and after pegylated interferon alfa- $2 b$ plus ribavirin therapy. J. Transl. Medicine 4:25-30.

5- Harman D. (1995). Role of antioxidants nutrients in aging. Overview. Age 18(2): 51-62.

6- Grattagliano I, Russmann S, Palmieri VO, Juni P, Bihl F, Portincasa P, Palasciano G and Lauterburg BH (2004): Low membrane protein sulfhydryls but not G6PD deficiency predict ribavirin-induced hemolysis in hepatitis C. Hepatology 39(5):1248 -1255.

7- Chrobot AM, SzaflarskaSzczepanik A and Drewa G (2000). Antioxidant defense in children with chronic viral hepatitis B and C. Med. Sci. Monit., 6 (4):713-718.

8- Pak SG and Nikitin EV (1991): Status of the processes of free radical oxidation and antioxidation system in patients with severe course of hepatitis B. Klin. Mad. Mosk., 69(9): 54-57.

9- Karabulut AB, Sonmez E, Bayindir Y, Gozukara E (2002): A comparison of erythrocyte superoxide dismutase and catalase activity in patients with hepatitis C infection. Turk. J. Med. Sci., 32: 313-316.

10- Boya $P$, de la Peña $A$, Beloqui
O, Larrea
E, Conchillo

M, Castelruiz

Y, Civeira
MP, Prieto J. (1999):

Antioxidant status and glutathione metabolism in peripheral blood mononuclear cells from patients with chronic hepatitis C. J. Hepatol., 31(5):808-814.

11- Dikici I, Mehmetoglu I, Dikici $\mathbf{N}$, Bitirgen $M$, Kurban $\mathbf{S}$ (2005). Investigation of oxidative stress and some antioxidants in patients with acute and chronic viral hepatitis B and the effect of interferon- $\alpha$ treatment. Clin Biochem., 38(2):1141-1144.

12- Moran LK, Gutteridge JMC, Quinlan GJ. (2001). Thiols in cellular redox signaling and control. Curr. Med. Chem., 8 (7):763-772.

13- Biswas S, Chida AS, Rahman I. (2006): Redox modifications of protein-thiols: Emerging roles in cell signaling. Biochem. Pharmacol., 71 (5):551-564.

14- Rokutan K, Johnston RB Jr, Kawai K. (1994): Oxidative stress induces S-thiolation of specific proteins in cultured gastric mucosal cells. Am. J. Physiol., 266(2 pt. 1): 247-54.

15- Iciek M, Chwatko G, LorencKoci E, Bald $\mathbf{E}$ and Włodek $L$ (2004). Plasma levels of total, free and protein bound thiols as well as sulfane sulfur in different age groups of rats. Acta Biochimica Polonica 51(3):815824.

16- Taylan E and Resmi H. (2010). The analytical performance of a microplate method for total sulfhydryl measurement in biological samples. Turkish J.Biochem., 35 (3): 275-278. 
17- Mutlu-Turkoglu U, Ademoglu E, Turkoglu S, Badur S, Uysal M, and Toker G. (1997): The effects of interferon-alpha on serum lipid peroxidation and total thiol content in patients with chronic active hepatitis-C. Res. Commun. Mol. Pathol. Pharmacol., 96 (3): 357-61.

18- Romero MJ, Bosch-Morell F, Romero B, Rodrigo JM, Serra MA, Romero FJ. (1998): Serum malondialdehyde: possible use for the clinical management of chronic hepatitis C patients. Free Radical Biol. Med., 25(9):993-7.

19- Beutler E, Duron O, Kelly BM. (1963): Improved method for the determination of blood GSH. J. Lab. \& Clin. Med., 61: 882-890.

20- Nishikimi, M, Roa NA, and Yogi K (1972). Determination of superoxide dismutase. Biochem. Bioph. Res. Common., 46: 845 854

21- Hu ML. (1994): Measurement of protein thiols groups and glutathione in plasma. Methods Enzymol., 233:380-385.

22- Lowery OH, Rosebrough NJ, Farr AL and Randall LJ (1951): Protein measurement with the Folin phenol reagent. J. Biol. Chem., 193(1): 265-275.

23- Strickland GT, Elhefni H, Salman T, Waked I, AbdelHamid M, Mikhail N, Esmat G, and Fix A (2002). Role of hepatitis $\mathrm{C}$ infection in chronic liver disease in Egypt .Am. J. Trop. Med. Hyg., 67(4): 436-442.

24- Sua'rez M, Beloqui O, Ferrer JV, Gil B, Qian C, Garcia N, Civeira P,Prieto J (1993): Glutathione depletion in chronic hepatitis C. International Hepatology Communications 1(4): 215-221.

25- Serejo F, Emerit I, Filipe PM, Fernandes AC, Costa MA, Freitas JP, de Moura MC (2003): Oxidative stress in chronic hepatitis $\mathrm{C}$ : the effect of interferon therapy and correlation with pathological features. Can J Gastroenterol., 17(11):644-50.

26- Camps J., castilla A., Ruiz J., Civera MP and Prielo J. (1993). Randomized trial of lymphoblastoid alpha interferon in chronic hepatitis $\mathrm{C}$ : effect on inflammation, fibrogenesis and viremia. J. Hepatology 17(3): 390-6.

27- Ko WS, Guo CH, Yeh MS, Lin LY, Hsu GSW, Chen PC, Luo MC, Lin CY. (2005). Blood micronutrient, oxidative stress, and viral load in patients with chronic hepatitis C. World J Gastroenterol. 11(30): 46974702.

28- Irmisch G, Hoeppner J, Thome J, Richter J, Fernow A, , Reisinger EC, Lafrenz M, Loebermann M (2011). Serum fatty acids, antioxidants, and treatment response in hepatitis $\mathrm{C}$ infection: Greater polyunsaturated fatty acid and antioxidant levels in hepatitis $\mathrm{C}$ responders. J. Clin. Lipidology 5: 288-293.

29- Serejo F, Costa A, Oliveira AG, Ramalho F, Batista A, Moura MC (2001). Alpha interferon improves liver fibrosis in chronic hepatitis C: Clinical significance of the serum of N-terminal 
propeptide of procollagen type III. Dig Dis Sci., 46: 1684-1689.

30- Bruno S, Battezzati PM, Bellati G, Manzin M, Crosignani M, Solforosi A, Maggioni

A, Borzio A, Ideo G, Podda M. (2001). Long term beneficial effects in sustained responders in interferon-alpha therapy for chronic hepatitis C. J. Hepatol., 34:748-55.

31- Canbakan B, Akin H, Tahan G, Tarcin O, Eren F, Atug O, Tahan V, Imeryuz N, Yapicier O, Avsar E, Tozun N. (2009). Ann Hepatol. 8(3):234-40.

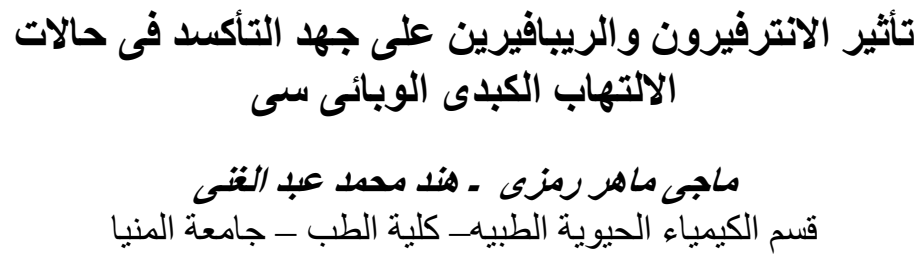

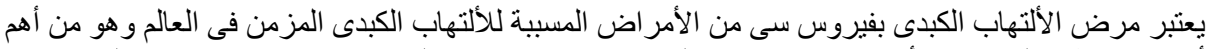

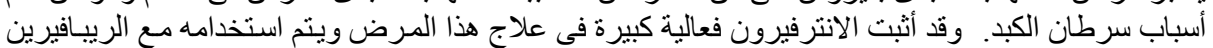

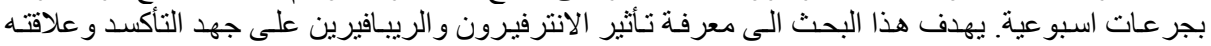
بأنزيمات الكبد.

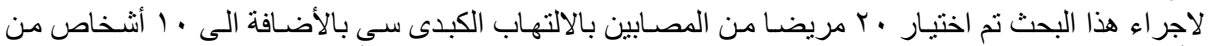

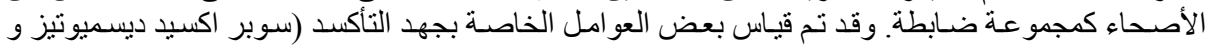

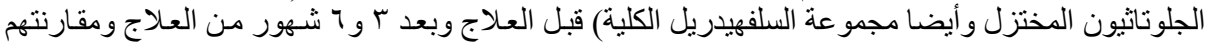

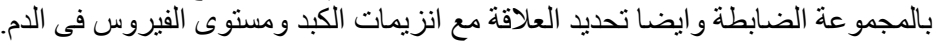

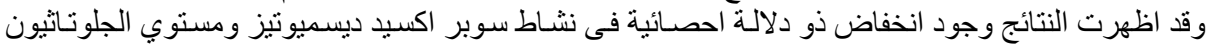

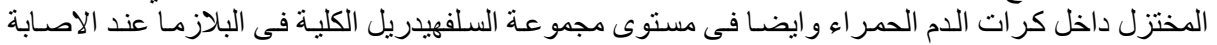

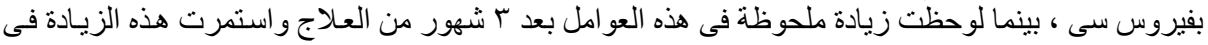

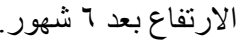

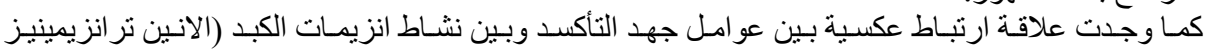

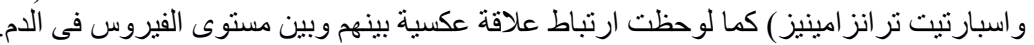

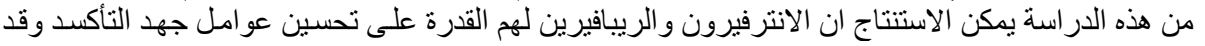

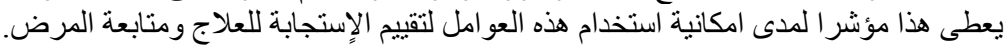

